\title{
Distracted by Binge-watching: Sources of Academic and Social Disruption in Students
}

\author{
Catherine Chambliss*, Carly Gartenberg, Dayna Honrychs, MaryAnn Elko, Ryan March, \\ Sydney McGill, Meredith Watters, Krystina Bayer, Claire Boylan, Alexa Hanson, Brittany \\ Hawley, Danny Ventura, and Richard Boss \\ Psychology Department, Ursinus College, USA
}

\author{
*Corresponding Author: Catherine Chambliss, Psychology Department, Ursinus College, USA, \\ Email: cchambliss@ursinus.edu
}

\begin{abstract}
In recent years, various technological developments have made managing potential distractions quite challenging for today's adolescents. This study revealed that Netflix binge watching appears to be disrupting academic success for many. The majority of the respondents identified this as an academic obstacle; Instagram and other social media also are disruptive for a majority of students. While sports viewing and electronic game playing were more distracting for male students than female students, female students reported greater problems with being sidetracked by social media sites. Developing skills for managing these potential distractions has become important for academic success.
\end{abstract}

Keywords: academic, distraction, technology, Netflix

\section{INTRODUCTION}

Many things compete for undergraduates' time and energy and potentially distract them from activities that would help them to achieve their academic and social goals. Various activities that occupy undergraduates' time have long been viewed as potential threats to their success. For example, in a study by Foss and Alexander (1996), both heavy viewers and non-viewers agreed that television viewing could have potentially harmful consequences. Previous investigations have found a negative relationship between some types of television viewing and academic achievement (Potter, 1987). The potential social consequences of distracting activities have also been explored previously. For example, Rosenblatt and Cunningham (1976) found a strong positive correlation between the household television use and family tension. Supporting these studies' negative portrayal of the correlates of television viewing, Krosnick et al. (2003) observed a negative association between perceived intelligence/school achievement and television watching. They also found peer contact to be significantly negatively associated with television watching.

However, other research partially contradicts these conclusions. For example, a study of undergraduate electronic media use (including time spent on social networking sites, email, chat/IM, cell phone communication or text messaging, video or online games, TV or movie viewing) by Jacobsen and Forste (2011) revealed that online communication facilitated rather than replaced face-to-face social interaction. However, this study did find negative academic consequences (a negative association between electronic use and GPA), paralleling the previous research. The present investigation was conducted in order to clarify the relationship between various potentially distracting activities (including electronic media use and the new potential threat posed by the option of "binge watching" programs) and both academic and social success among undergraduates. Participants' perception of their excessive involvement in the twelve activities was also assessed. The responses of men and women were compared because research has shown there to be sex differences in various sedentary activities (e.g., Clark et al., 2010).

\section{Methodology}

The sample consisted of 62 student volunteers enrolled in an introductory psychology course at a small, liberal arts college in the mid-Atlantic region of the U.S. (19 male and 43 female students). Students' ages ranged from 17 to 23 years (with a mean of 18.54 and S.D. of 1.02). 
Participants were asked to complete a 50 item self-report questionnaire assessing various demographic factors and how often the hours they spend on twelve common activities detract from their academic success. They also rated how often the hours they spend on these activities detract from their social and relationship success. Finally, they rated how often the time they spend on these activities seems excessive to them. The activities included the following: viewing sports on TV, binge watching Netflix and other non-sport TV programs, talking on the phone or Skyping, and playing videogames or cellphone games. In addition, participants reported time spent following and contributing to social media sites (Facebook, Twitter, Instagram, etc.), reading non-coursework content online, managing noncoursework email, socializing in person, exercising, and sleeping.

SPSS was used for all data analyses. Independent samples t-tests were conducted to compare men's and women's experience of the various sources of academic distraction.

\section{RESUltS}

A majority of college students $(64 \%)$ reported excessive binge watching of Netflix and other non-sport TV programs (Figure 1). Similarly, the majority $(58 \%)$ believe they excessively follow social media sites (Facebook, Twitter, Instagram, etc.). Almost half of the students $(49 \%)$ view themselves as spending an excessive amount of time sleeping. An independent samples t-test was conducted to compare men's and women's viewing of sports on TV. Significant differences emerged; males reported more excessive viewing sports on TV than females (males $\mathrm{x}=2.05$, s.d. $=1.22, \mathrm{n}=19$ versus females $\mathrm{x}=1.21$, s.d. $=.47, \mathrm{n}=43 ; \mathrm{t}=2.91$, $\mathrm{df}=20.34, \mathrm{p}<.01$, Figure 4).

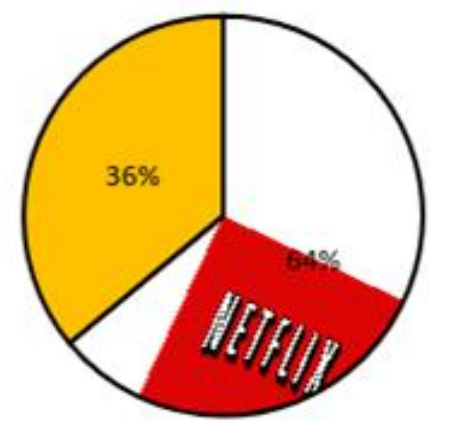

Binge Watch $\square$ Don't Binge Watch

Figure1. Percentage of undergraduates reporting Excessive Binge Watching (Netflix and Non-Sport TV Programs)

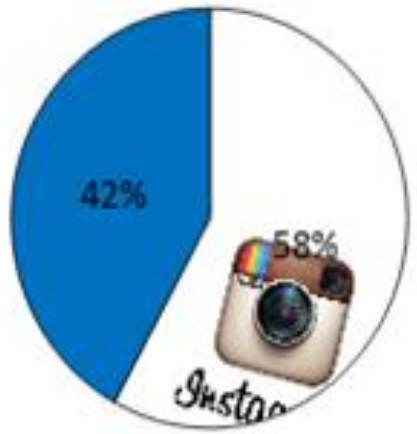

\section{Dexcessively Follow DDon't Excessively Follow}

Figure2. Percentage of undergraduates reporting Excessively Following Social Media Sites

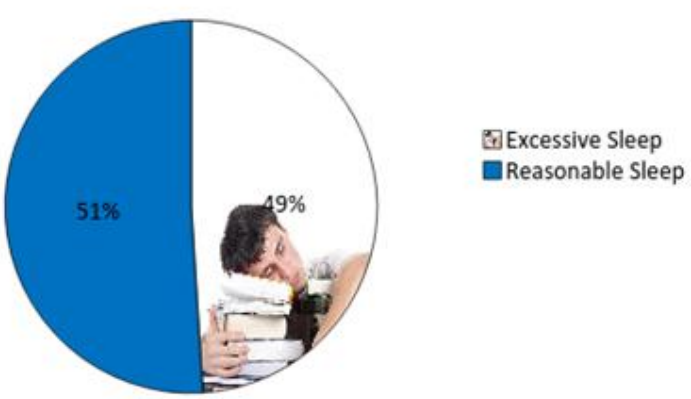

Figure3. Percentage of undergraduates reporting Excessive Sleeping

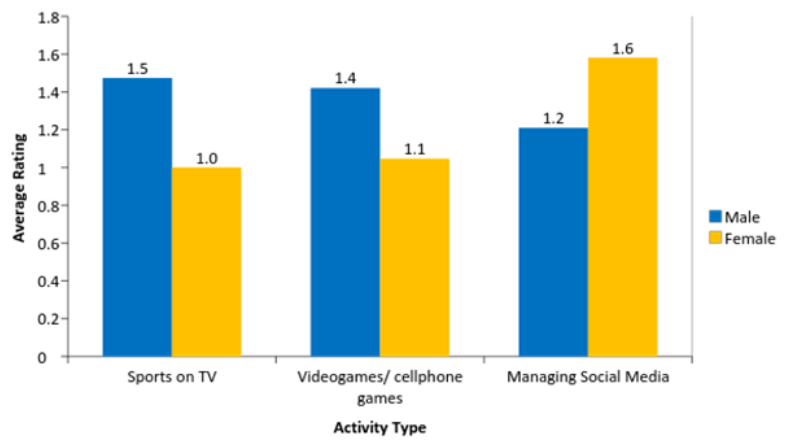

Figure4. Sex differences in the activities associated with excessive distraction (Sports: $t=2.91, d f=20.34$, $p<.01$; Videogames: $t=2.62, d f=22.53, p=.02$; Social Media: $t=2.39, d f=35.19, p=.02$ )

Another independent samples t-test was conducted to compare men's and women's playing of video or cell phone games. Significant differences emerged; male students reported greater playing of video or cell phone games than female students (males $\mathrm{x}=2.26$, s.d. $=1.33, \mathrm{n}=19$ versus females $\mathrm{x}=1.42$, s.d. $=$ $.70, \mathrm{n}=43 ; \mathrm{t}=2.62, \mathrm{df}=22.53, \mathrm{p}=.02)$.

An independent samples t-test comparing men's and women's time spent contributing to their own social media sites revealed significant sex differences. Female students spent more time 
building their own social media sites than male students (males $\mathrm{x}=1.74$, s.d. $=1.10, \mathrm{n}=19$ versus females $\mathrm{x}=2.47$, s.d. $=1.12, \mathrm{n}=43 ; \mathrm{t}=$ $2.39, \mathrm{df}=35.19, \mathrm{p}=.02)$.

Independent samples t-tests also revealed sex differences on three sources of academic disruptions. Men's academic performance was more compromised by viewing sports on TV (men: $\mathrm{x}=2.26$, s.d. $=1.24, \mathrm{n}=19$ versus women: $\mathrm{x}=1.16$, s.d. $=0.37, \mathrm{n}=43$ ) and playing videogames or cellphones games (men: $\mathrm{x}=2.32$, s.d. $=1.06, \mathrm{n}=19$ versus women: $\mathrm{x}=1.4$, s.d. $=$
$0.58, \mathrm{n}=43$ ) than was women's performance. Women's academic performance was more compromised by contributing to their own social media (men: $\mathrm{x}=1.84$, s.d. $=1.01, \mathrm{n}=19$ versus women: $\mathrm{x}=2.63$, s.d. $=1.05, \mathrm{n}=43$ ) than was men's performance.

Binge-watching and social media activities ranked among the top five sources of both academic and social disruption (Figures 5 and 6). In contrast, for the sample as a whole, email and sports viewing were the least academically and socially disruptive activities.

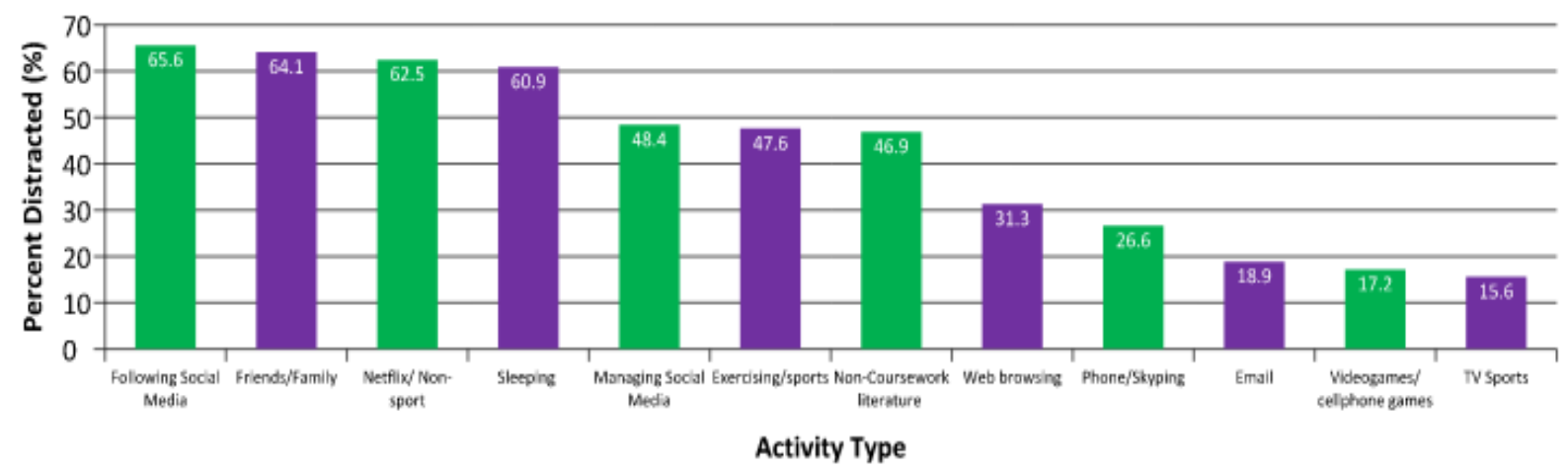

Figure5. Percentage of students attributing academic disruption to twelve activities

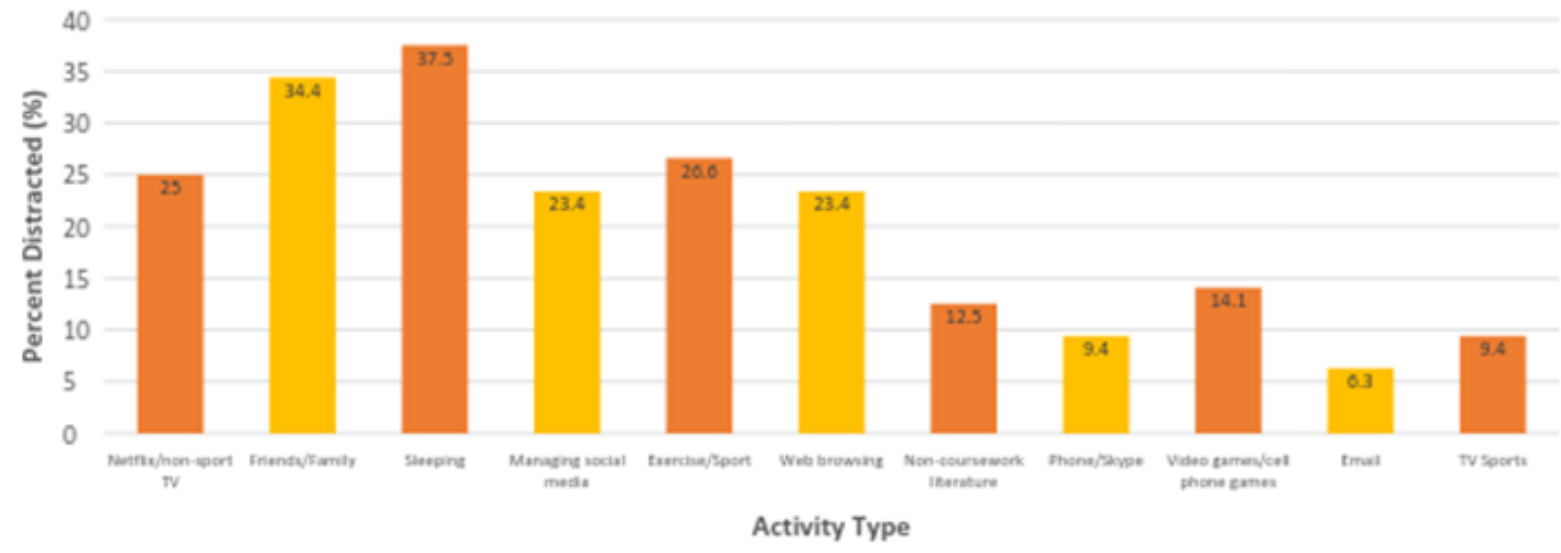

Figure6. Percentage of students attributing social disruption to twelve activities

\section{DISCUSSION}

Netflix binge watching appears to be problematically distracting many undergraduates and disrupting academic success for some. The majority of the respondents $(63 \%)$ identified this as an academic obstacle and $64 \%$ perceived this binge watching as excessive. These findings are consistent with those obtained earlier by Krosnick et al. (2003).

Following Instagram and other social media also seems to be disruptive for many students $(66 \%)$. Excessive sleeping was also identified as a common obstacle to achievement $(61 \%$ reported it to be disruptive).
A few differences between men and women emerged here. While sports viewing and electronic game playing were more distracting for men, women reported greater problems with being sidetracked by social media sites.

These findings suggest that recent technological developments have made managing one's response to potentially distracting activities more challenging than ever for students today. Since this study relied on self-report data, future research might seek to specify the impact of these distractions on both academic and social achievement more objectively. Assessing actual time spent on these activities and including outcome measures such as GPA might clarify matters. 


\section{REFERENCES}

[1] Clark, B. K., Sugiyama, T., Healy, G. N., Salmon, J., Dunstan, D. W., Shaw, J. E., \& Owen, N. (2010). Socio-demographic correlates of prolonged television viewing time in Australian men and women: The AusDiab study. Journal of Physical Activity and Health, 7(5), 595-601.

[2] Foss, K. A., \& Alexander, A. F. (1996). Exploring the margins of television viewing. Communication Reports, 9(1), 6167.

[3] Jacobsen, W. C., \& Forste, R. (2011). The wired generation: Academic and social outcomes of electronic media use among university students. Cyberpsychology,
Behavior, and Social Networking, 14(5), 275280.

[4] Krosnick, J. A., Anand, S. N., \& Hartl, S. P. (2003). Psychosocial predictors of heavy television viewing among preadolescents and adolescents. Basic and Applied Social Psychology, 25(2), 87-110.

[5] Potter, W. J. (1987). Does television viewing hinder academic achievement among adolescents? Human Communication Research, 14(1), 27-46.

[6] Rosenblatt, P. C., \& Cunningham, M. R. (1976). Television watching and family tensions. Journal of Marriage and the Family, 105-111.

Citation: Catherine Chambliss, Carly Gartenberg, Dayna Honrychs, MaryAnn Elko, Ryan March, Sydney McGill, et al. Distracted by Binge-watching: Sources of Academic and Social Disruption in Students. ARC Journal of Pediatrics. 2017; 3(1):14-17. doi:dx.doi.org/ 10.20431 /2455-5711.0301004.

Copyright: (C) 2017 Authors. This is an open-access article distributed under the terms of the Creative Commons Attribution License, which permits unrestricted use, distribution, and reproduction in any medium, provided the original author and source are credited. 